\title{
EFFECT OF SOME HEAVY METALS ON GROWTH OF SCENEDESMUS OBLIQUUS (TURPIN) KÜTZING
}

\author{
Rawheya A. Salah EI Din ${ }^{1}$; Fatma A. Gharib ${ }^{2}$; Safeya M. Ghazy ${ }^{2}$ and \\ Emad Y. R. Johny ${ }^{3}$. \\ 1- Botany \& Microbiology Dept., Fac. of Sci., Al Azhar Univ. (Girl Branch). \\ 2- Botany Depart. Fac. of Sci., Helwan Univ. \\ 3- Collège de la Salle-Frères-Daher.
}

\begin{abstract}
The effect of concentrations of copper $\left(0.5,1.5 \mathrm{mg} \mathrm{l}^{-1}\right)$, lead $\left(10,40, \mathrm{mg} \mathrm{l}^{-1}\right)$ and zinc $\left(0.05\right.$ and $\left.0.5 \mathrm{mgl}^{-1}\right)$ singly or in combination on growth of Scenedesmus obliquus was studied. The results showed that there is a difference between the effects of each metal singly and in combinations with each others. Generally, heavy metals decreased the growth of Scenedesmus obliquus. High concentration of copper uptake exceeds its uptake in low concentration (58 and $42 \%$, respectively). While the uptake of lead and zinc in low concentrations exceeds their uptake in high concentrations with percentages of $(87 \%$, $86 \%, 13 \%$ and $14 \%$, respectively). Zinc uptake in combinations was dominant over the two other metals. The effect of heavy metals on ultrastructure of Scenedesmus obliquus by using the Transmission Electron Microscope was investigated.
\end{abstract}

Key Words: Heavy metals, Scenedesmus obliquus, Ultrastructure.

\section{Introduction}

Heavy metal pollution is an issue of great environmental concern. Heavy metals are released from prevalent municipal industrial, agricultural and domestic wastes; they modify the structure and productivity of aquatic ecosystems (Magdaleno et al., 1997; Osman et al., 2004). Also, heavy metals are known to disrupt algal metabolism either by inactivating the photosynthetic machinery, enzymatic pathways or altering the nutrient transport and availability (Mallick and Rai, 1992; Rai $\boldsymbol{e t}$ al., 1998).

A number of publications discussed water quality and phytoplankton distribution of the River Nile in Egypt (Kobbia et al., 1993; Toulibah, 1996; and Shaaban-Dessouki et al. 2004).

Much research information has been amassed on the effect of heavy metal toxicity on growth and uptake of microorganisms. While, the knowledge of the toxicity and general uptake of single species of heavy metals by algae is increasing, relatively little is known about the combined effects of two or more metals (Ting et al., 1991). The present work aims to verify the ability of magnitudes of Scenedesmus obliquus, isolate from the River Nile, to tolerate single and combined heavy metal concentrations. 


\section{Materials and Methods}

S. obliquus (Turpin) Kützing sample was collected during 2004, spring season from El Maadi Yakht Club in River Nile. Elimination of contaminants was done in the field by filtration method, for obtaining axenic culture was carried out according to (Guillard, 1995). Where, the identification was according to (Bourrelly, 1968). The best growth conditions were at the seventh day, 2000 Lux light intensity $\mathrm{pH} 8$ at $30{ }^{\circ} \mathrm{C}$ using BG-11 medium (Allen and Stanier, 1968) modify No. 11 (Hughes et al., 1958) copper, lead and zinc, in two concentrations of each heavy metal were used in singly or in combination. The concentrations of the metals ware $0.5,1.5 \mathrm{mg} . \mathrm{l}^{-1}$ for copper, $10,40 \mathrm{mg} . \mathrm{l}^{-1}$ for lead and 0.05 and 0.5 mg. $1^{-1}$ for zinc. Determination of dry weight, chlorophylls $a$ and $b$ was carried out according to the method of Jeffrey and Humphrey (1975). The total soluble carbohydrates were determined using anthrone technique according to Umbriet $\boldsymbol{e t}$ al. (1969). Total soluble proteins were determined according to the method of Lowry et al. (1951) and the determination of crude lipid was determined according to the method of Padmini Sreenivasa Rao et al. (1986). The preparation of algal cell for transmission electron microscope was carried out according to the method of (Palade $\boldsymbol{e t}$ al., 1952) and the sections were then examined photographed by a JEOL 1200 EXII transmission electron microscope.

\section{Results}

Under different doses of copper and lead the photosynthetic activities of S. obliquus cell varied considerably with various doses accompanied with a remarkable decrease in dry weight (Table 1). With regard to chlorophyll $a$ and $b$, it was evident that the highest concentration of copper and lead induced decrease in both chlorophylls contents.

It was clearly evident that chlorophyll $a$ and $b$ content in $S$. obliquus cells increased under low concentrations of zinc $\left(2.03 \pm 0.04\right.$ and $0.69 \pm 0.05 \mathrm{mg} \mathrm{l}^{-1}$, respectively) compared to the influence of copper and lead and it decreased under high dose.

All the parameters studied for S. obliquus were decreased gradually with increasing concentrations of heavy metals mixture (Table 1). However a conspicuous variation was registered in the magnitudes the uptake of each metal in the mixture relevant to that for each metal alone. Also, the data indicate that weigh gain, chlorophylls $a$ and $b$ in S. obliquus decrease dramatically with low and high concentrations of the three combined metals as compared to control, On the other hand, mixture $3\left(0.5 \mathrm{mg} \mathrm{l}^{-1} \mathrm{Cu}+0.05 \mathrm{mg} \mathrm{l}^{-1} \mathrm{Zn}\right)$ and mixture $6\left(40 \mathrm{mg} \mathrm{l}^{-1}\right.$ $\mathrm{Pb}+0.5 \mathrm{mg} \mathrm{l}^{-1} \mathrm{Zn}$ ) increased the amount of chlorophylls $a$ and $b$ of $S$. obliquus compared to the other mixtures (Table 1). 
Table (1) Effect of different heavy metals concentrations supplemented singly or in combination to the algal culture media on dry weight, chlorophylls a and $b$ of Scenedesmus obliquus, grown for 7 days.

\begin{tabular}{|c|c|c|c|c|}
\hline \multicolumn{2}{|c|}{$\begin{array}{c}\text { Heavy metals } \\
\text { Concentration }\left(\mathrm{mg} \mathrm{l}^{-1}\right) \\
\end{array}$} & $\begin{array}{l}\text { Dry weight } \\
\left(\mathrm{mg} \mathrm{l}^{-1}\right)\end{array}$ & $\begin{array}{c}\text { Chlorophyll } a \\
\left(\mathrm{mg} \mathrm{l}^{-1}\right)\end{array}$ & $\begin{array}{c}\text { Chlorophyll } b \\
\left(\mathrm{mg} \mathrm{l}^{-1}\right)\end{array}$ \\
\hline \multicolumn{2}{|l|}{ Control } & $820 \pm 10$ & $2.75 \pm 0.01$ & $0.92 \pm 0.04$ \\
\hline \multirow{2}{*}{ Copper } & 0.5 & $600 \pm 5$ & $1.55 \pm 0.02$ & $0.45 \pm 0.05$ \\
\hline & 1.5 & $490 \pm 8$ & $1.06 \pm 0.01$ & $0.35 \pm 0.06$ \\
\hline \multirow{2}{*}{ Lead } & 10 & $460 \pm 6$ & $0.96 \pm 0.02$ & $0.29 \pm 0.01$ \\
\hline & 40 & $420 \pm 5$ & $0.82 \pm 0.02$ & $0.27 \pm 0.02$ \\
\hline \multirow{2}{*}{ Zinc } & 0.05 & $791 \pm 6$ & $2.03 \pm 0.04$ & $0.69 \pm 0.05$ \\
\hline & 0.5 & $435 \pm 10$ & $1.03 \pm 0.02$ & $0.31 \pm 0.01$ \\
\hline \multicolumn{2}{|c|}{$\begin{array}{c}\text { Mixture 1 } \\
0.5 \mathrm{Cu}+10 \mathrm{~Pb}\end{array}$} & $630 \pm 8$ & $1.82 \pm 0.01$ & $0.61 \pm 0.02$ \\
\hline \multicolumn{2}{|c|}{$\begin{array}{c}\text { Mixture } 2 \\
1.5 \mathrm{Cu}+40 \mathrm{~Pb}\end{array}$} & $490 \pm 6$ & $1.35 \pm 0.02$ & $0.39 \pm 0.03$ \\
\hline \multicolumn{2}{|c|}{$\begin{array}{c}\text { Mixture 3 } \\
0.5 \mathrm{Cu}+\mathbf{0 . 0 5} \mathrm{Zn}\end{array}$} & $700 \pm 9$ & $2.4 \pm 0.1$ & $0.78 \pm 0.01$ \\
\hline \multicolumn{2}{|c|}{$\begin{array}{c}\text { Mixture 4 } \\
1.5 \mathrm{Cu}+0.5 \mathrm{Zn}\end{array}$} & $480 \pm 7$ & $0.78 \pm 0.01$ & $0.24 \pm 0.01$ \\
\hline \multicolumn{2}{|c|}{$\begin{array}{c}\text { Mixture 5 } \\
10 \mathrm{~Pb}+0.05 \mathrm{Zn}\end{array}$} & $410 \pm 6$ & $0.83 \pm 0.01$ & $0.28 \pm 0.02$ \\
\hline \multicolumn{2}{|c|}{$\begin{array}{c}\text { Mixture } 6 \\
40 \mathrm{~Pb}+0.5 \mathrm{Zn} \\
\end{array}$} & $530 \pm 7$ & $1.73 \pm 0.2$ & $0.57 \pm 0.04$ \\
\hline \multicolumn{2}{|c|}{$\begin{array}{c}\text { Mixture } 7 \\
\mathbf{0 . 5} \mathrm{Cu}+\mathbf{1 0} \mathrm{Pb}+\mathbf{0 . 0 5} \mathrm{Zn} \\
\end{array}$} & $360 \pm 8$ & $0.73 \pm 0.01$ & $0.21 \pm 0.5$ \\
\hline \multicolumn{2}{|c|}{$\begin{array}{c}\text { Mixture 8 } \\
1.5 \mathrm{Cu}+40 \mathrm{~Pb}+0.5 \mathrm{Zn}\end{array}$} & $320 \pm 6$ & $0.57 \pm 0.04$ & $0.17 \pm 0.9$ \\
\hline
\end{tabular}

The data in Table (2) indicate that the soluble carbohydrates and soluble proteins of $S$. obliquus decrease dramatically with high concentrations of copper, lead and zinc compared to control. Also, under different doses of copper, lead and zinc the lipid behave almost similarly to protein and carbohydrates.

Combination of the three metals with two different concentrations induced retardation in carbohydrate, proteins and lipid. Irrespective, of some 
minor fluctuations slightly stimulated in lipid biosynthesis production with mixture $7\left(0.5 \mathrm{mg} \mathrm{l}^{-1} \mathrm{Cu}+10 \mathrm{mg} \mathrm{l}^{-1} \mathrm{~Pb}+0.05 \mathrm{mg} \mathrm{l}^{-1} \mathrm{Zn}\right)$ and mixture $8\left(1.5 \mathrm{mg} \mathrm{l}^{-1}\right.$ $\mathrm{Cu}+40 \mathrm{mg} \mathrm{l}^{-1} \mathrm{~Pb}+0.5 \mathrm{mg} \mathrm{l}^{-1} \mathrm{Zn}$ ) (Table 2).

Table (2) Effect of different heavy metals concentrations supplemented singly or in combination to the algal culture media on carbohydrates, protein and lipid of Scenedesmus obliquus, grown for $\mathbf{7}$ days.

\begin{tabular}{|c|c|c|c|c|}
\hline \multicolumn{2}{|c|}{$\begin{array}{c}\text { Heavy metals } \\
\text { Concentration }\left(\mathrm{mg.l}^{-1}\right)\end{array}$} & $\begin{array}{c}\text { Carbohydrates } \\
\left.\text { (mg.g dry weight }^{-1}\right)\end{array}$ & $\begin{array}{c}\text { Protein } \\
\left(\text { (mg.g dry }^{-1}\right. \\
\left.\text { weight }^{-1}\right)\end{array}$ & $\begin{array}{l}\text { Lipid (mg.g } \\
\left.\text { dry weight }{ }^{-1}\right)\end{array}$ \\
\hline \multicolumn{2}{|l|}{ Control } & $9.2 \pm 0.2$ & $0.85 \pm 0.04$ & $0.45 \pm 0.01$ \\
\hline \multirow{2}{*}{ Copper } & 0.5 & $7.9 \pm 0.5$ & $0.68 \pm 0.05$ & $0.35 \pm 0.01$ \\
\hline & 1.5 & $6.8 \pm 0.9$ & $0.59 \pm 0.06$ & $0.30 \pm 0.05$ \\
\hline \multirow{2}{*}{ Lead } & 10 & $6.2 \pm 0.2$ & $0.53 \pm 0.01$ & $0.27 \pm 0.01$ \\
\hline & 40 & $5.4 \pm 0.5$ & $0.47 \pm 0.02$ & $0.22 \pm 0.01$ \\
\hline \multirow{2}{*}{ Zinc } & 0.05 & $8.3 \pm 0.1$ & $0.75 \pm 0.05$ & $0.39 \pm 0.01$ \\
\hline & 0.5 & $5.9 \pm 0.5$ & $0.55 \pm 0.01$ & $0.21 \pm 0.02$ \\
\hline \multicolumn{2}{|c|}{$\begin{array}{c}\text { Mixture } 1 \\
0.5 \mathrm{Cu}+10 \mathrm{~Pb}\end{array}$} & $8.4 \pm 0.1$ & $0.7 \pm 0.02$ & $0.35 \pm 0.01$ \\
\hline \multicolumn{2}{|c|}{$\begin{array}{c}\text { Mixture 2 } \\
1.5 \mathrm{Cu}+40 \mathrm{~Pb}\end{array}$} & $6.8 \pm 0.9$ & $0.49 \pm 0.03$ & $0.27 \pm 0.05$ \\
\hline \multicolumn{2}{|c|}{$\begin{array}{c}\text { Mixture 3 } \\
0.5 \mathrm{Cu}+\mathbf{0 . 0 5} \mathrm{Zn} \\
\end{array}$} & $7.4 \pm 0.5$ & $0.68 \pm 0.01$ & $0.32 \pm 0.01$ \\
\hline \multicolumn{2}{|c|}{$\begin{array}{c}\text { Mixture 4 } \\
1.5 \mathrm{Cu}+0.5 \mathrm{Zn}\end{array}$} & $5.5 \pm 0.3$ & $0.48 \pm 0.04$ & $0.22 \pm 0.03$ \\
\hline \multicolumn{2}{|c|}{$\begin{array}{c}\text { Mixture } 5 \\
10 \mathrm{~Pb}+0.05 \mathrm{Zn}\end{array}$} & $5.2 \pm 0.2$ & $0.46 \pm 0.02$ & $0.30 \pm 0.02$ \\
\hline \multicolumn{2}{|c|}{$\begin{array}{c}\text { Mixture } 6 \\
40 \mathrm{~Pb}+0.5 \mathrm{Zn} \\
\end{array}$} & $6.7 \pm 0.1$ & $0.51 \pm 0.01$ & $0.28 \pm 0.05$ \\
\hline \multicolumn{2}{|c|}{$\begin{array}{c}\text { Mixture } 7 \\
0.5 \mathrm{Cu}+10 \mathrm{~Pb}+0.05 \mathrm{Zn} \\
\end{array}$} & $2.6 \pm 0.1$ & $0.24 \pm 0.02$ & $0.23 \pm 0.01$ \\
\hline \multicolumn{2}{|c|}{$\begin{array}{c}\text { Mixture } 8 \\
1.5 \mathrm{Cu}+40 \mathrm{~Pb}+0.5 \mathrm{Zn} \\
\end{array}$} & $2.0 \pm 0.1$ & $0.15 \pm 0.01$ & $0.20 \pm 0.05$ \\
\hline
\end{tabular}


In Figure (1 A - K) revealed the synergism and antagonism between metal to each other. In spite of concentration of single metal uptake high concentration of cupper slightly increased the percentage of uptake to 58\% compared to $42 \%$ at low concentration. In contrast, the uptake of low concentrations of lead and zinc $(87 \%, 86 \%$, respectively) were higher than their corresponding high doses uptake (13\% and $14 \%$ respectively) (Figure $1 \mathrm{~A}-\mathrm{C}$ ).
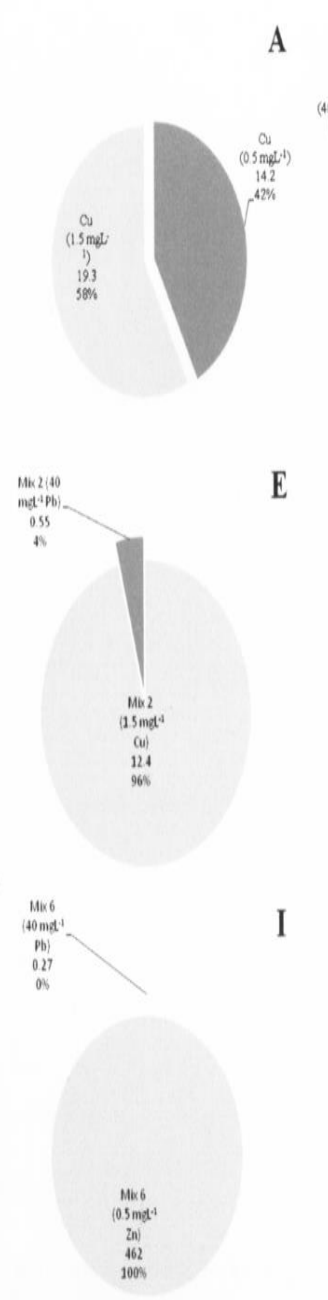

$A$

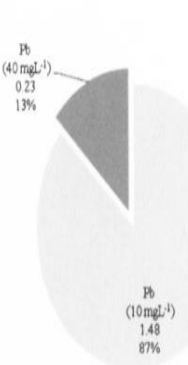

B

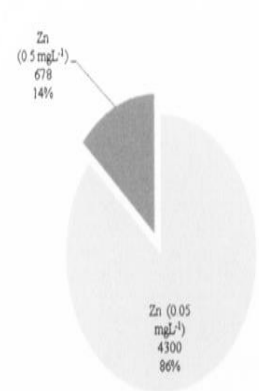

E
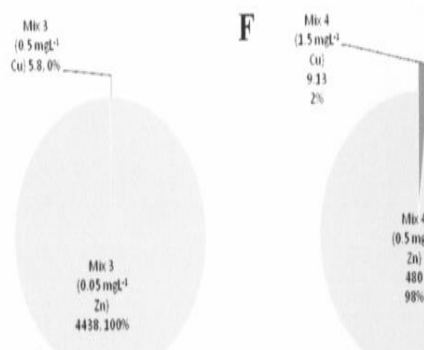

C

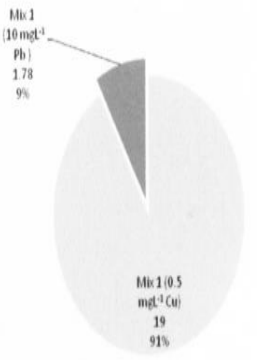

G

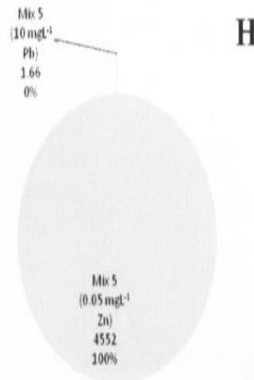

Figure (1 A- K) synergism and antagonism of heavy metals absorption related to each other. 
On the other hand, the two metal combinations Figure (1 D - K) behave differently, the low and high concentrations of copper uptake in mixture was dominated over the lead with percentage of (91 and $96 \%$ respectively). Meanwhile, the presence of copper and lead at the combination with zinc was almost neglected with an amount of $100 \%$ zinc and $0.00 \%$ copper and lead at low concentration. While, at high concentration the percentages of uptake were $98 \%$ zinc and $2 \%$ copper.

In regard, the three metal combinations zinc was dominated over the two other metals and behave almost as two metals combination, at low and high concentrations zinc uptake were $100 \%$ and $95 \%$ respectively.

Plate I (A - G) reveal effect on the internal structure of the algal cells under the stress of copper and zinc compared to the control. The ultrastructural appearance of $S$. obliquus cultured in $1.5 \mathrm{mgl}^{-1}$ copper (Plate 1C, D and E) was relatively normal except for focally increased vacuolation in the cytoplasm. These vacuoles appeared occupied by electron-opaque precipitates of the metal. Damage of cytoplasm contained abundant dense bodies. Also, shrinking phenomenon was observed in treated cells.

On the other hand, the electron photomicrographs of thin sections of $S$. obliquus cells growing in low concentration of zinc $0.05 \mathrm{mgl}^{-1}$ (Plate $1 \mathrm{~F}$ and $\mathrm{G}$ ) revealed shrinking and malformations of the cells as well as tangled mass of the cell contents in net format $(6000 \times$ and $70 \mathrm{k} \times)$ magnifications. The cytoplasm contained abundant dense bodies and lipid droplets. Uneven surface texture along with lot of irregular surface format was observed as roughly stellate outline. 


\section{Plate I (A-B)}

Control Cell

\section{Under Transmission Electron Microscope}
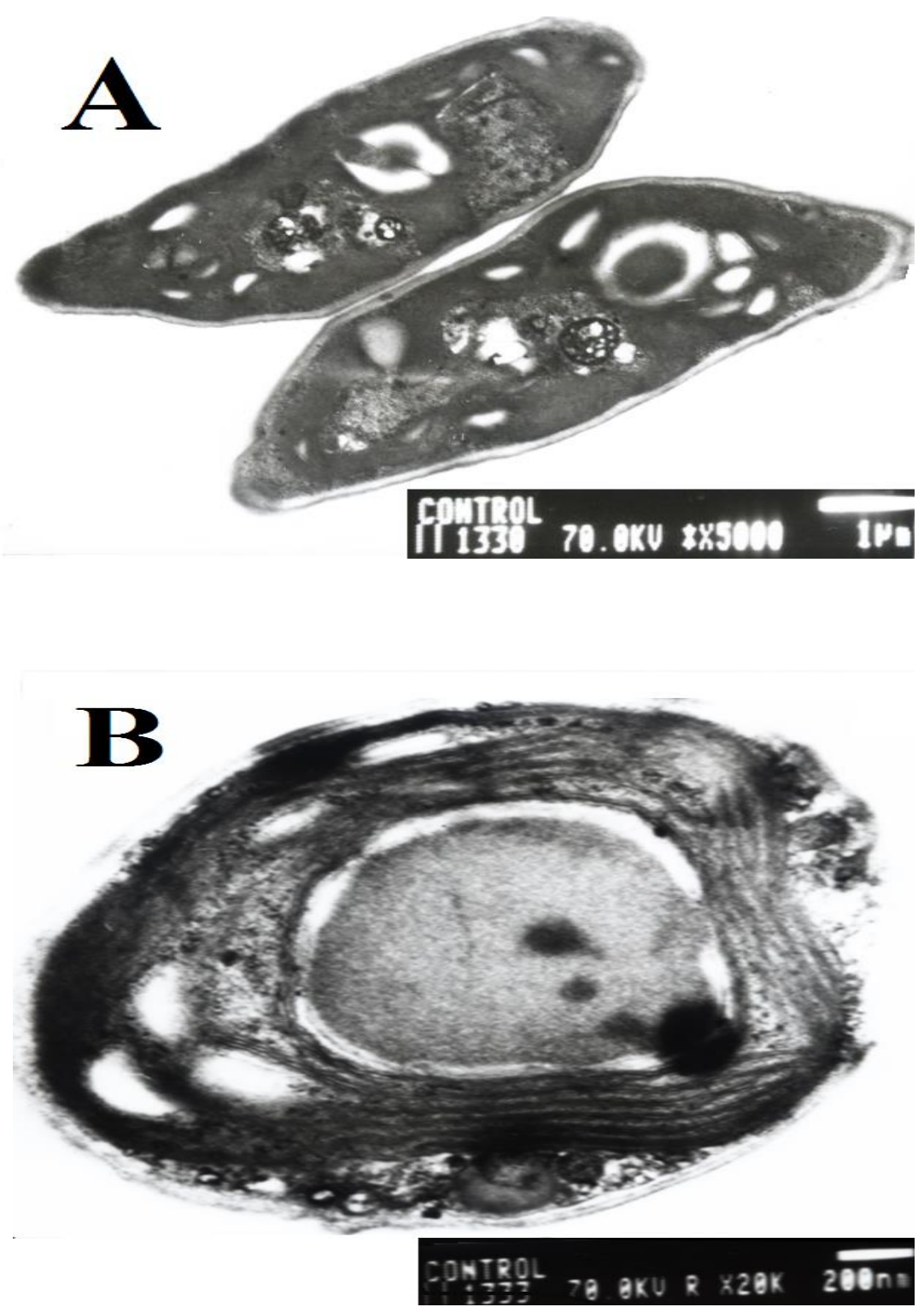


\section{Plate I (C-E)}

Treated Cell: Under High Concentration of Copper

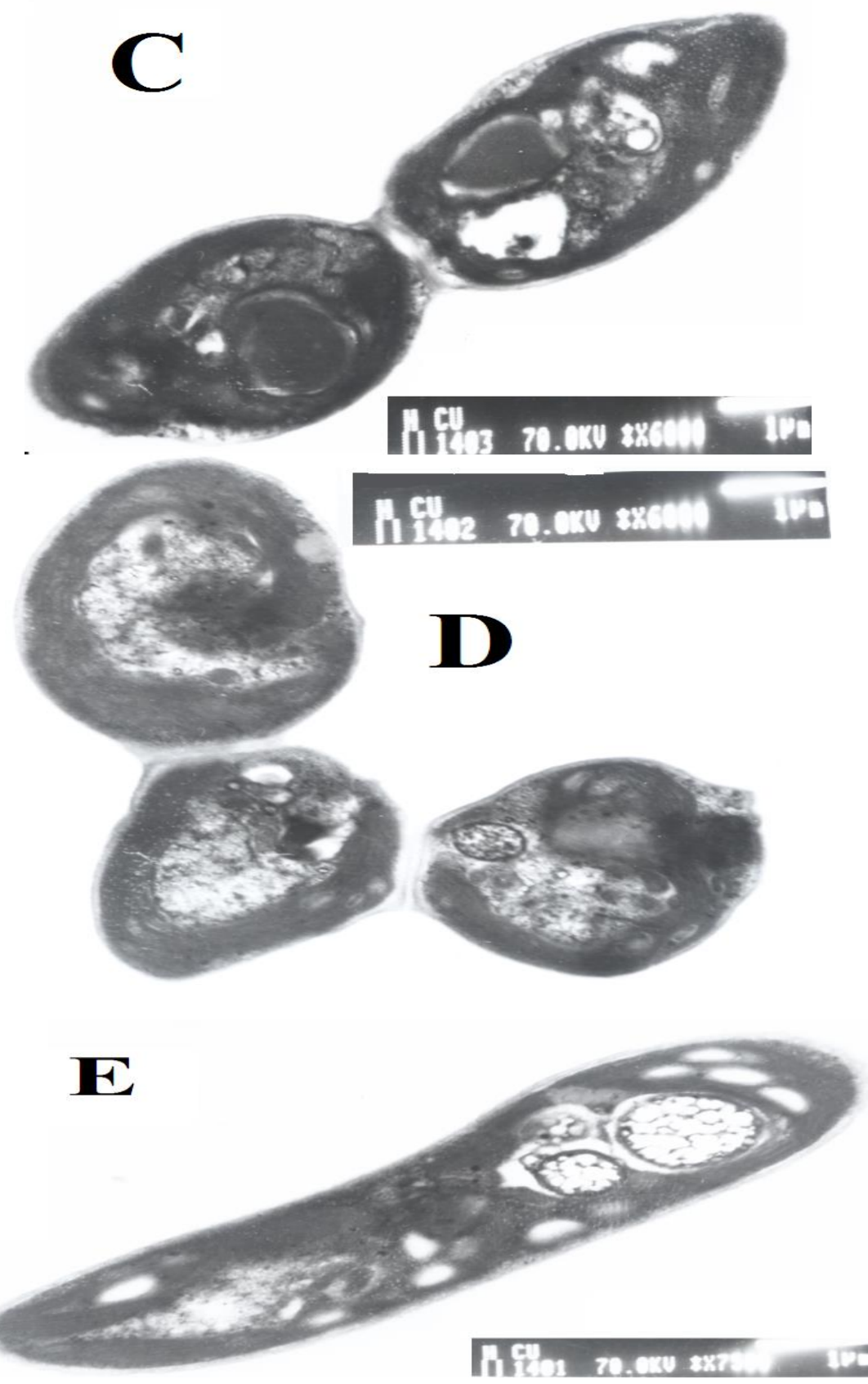


Effect of some heavy metals on growth of Scenedesmus obliquus (Turpin) Kützing.

\section{Plate I (F-G)}

Treated Cell: Under Low Concentration of Zinc
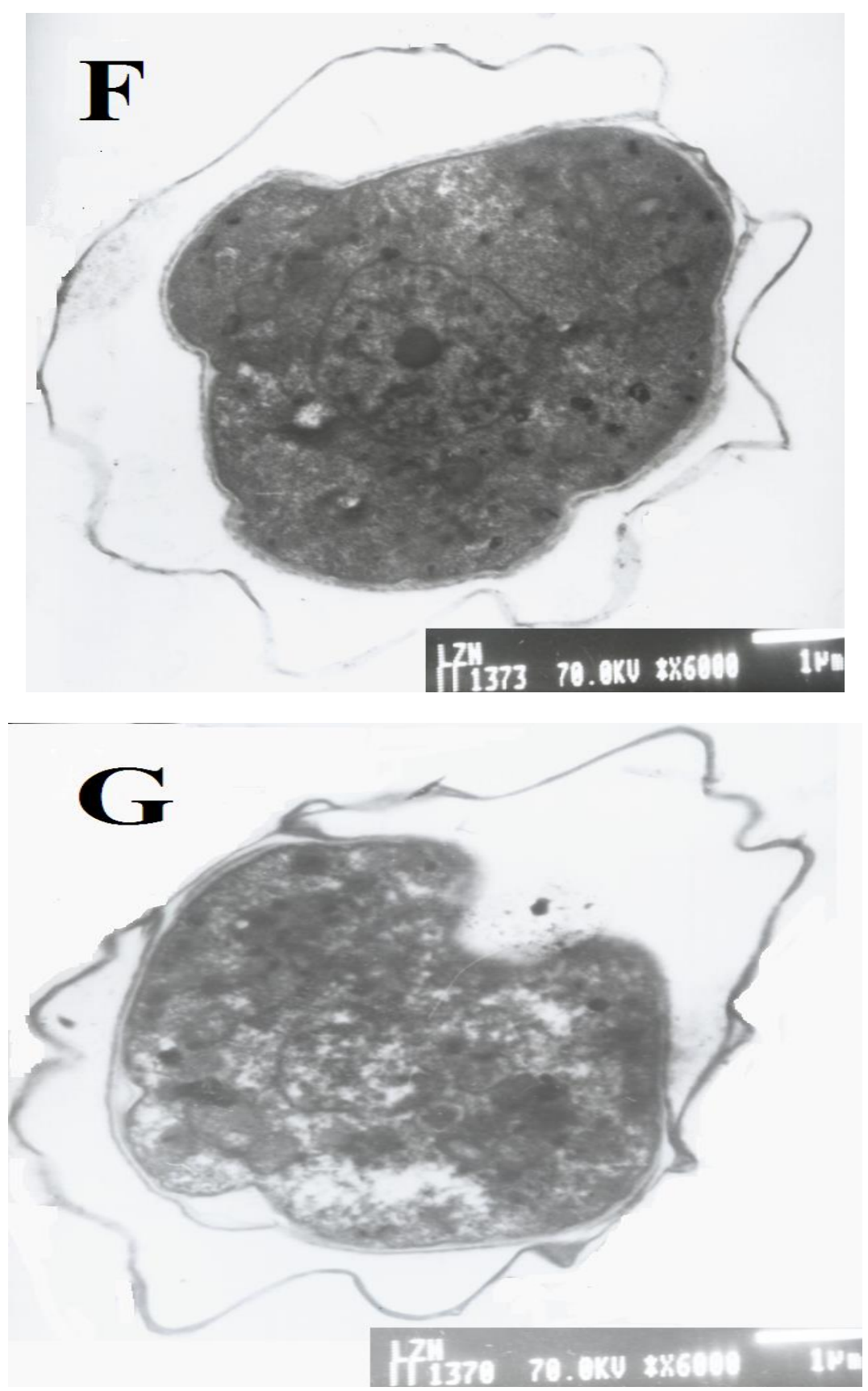


\section{Discussion}

The reduction in chlorophyll $a$ contents of $S$. obliquus recorded in this study may be due to the substitute of the central $\mathrm{Mg}^{2+}$ in the chlorophyll molecule, a process that lowers the fluorescence quantum yield and results in a shift in fluorescence spectrum, an interpretation that appears in harmony with the finding of Küpper et al. (1996). Heavy metals, may probably act on PSII at a common site(s) located at either the oxidative side (Krupa et al., 1993) or the reducing side (Jegerschöld et al., 1995).

The data demonstrated in this study reveals variability in sensitivity of $S$. obliquus toward the applied heavy metals a phenomenon that may be attributed to the physiological status of the organism and the mode of action of applied heavy metals. In this connection Olsson et al. (1979) had clarified the importance of proteins and lipoproteins in trapping metals as means of detoxifying them within the cell. Bariaud et al. (1985) concluded that the mechanism of the resistance depends upon the algae and the metal involved.

In general, more than one heavy metal found in the environment polluted. Also, toxins are rarely present in isolation and they may interact with other substances. The combined effect of several toxins may be the addition of one mortality to another; one increases the mortality caused by the other (synergy) that mean if the toxic effects are additive, the sum of the growth reductions for each of the metals acting alone should be the same as the reduction caused by all metals acting together. In contrast to the synergistic effect, one reduces the mortality caused by the other is antagonism (Clark et al., 1997). Only few and limited information concern with the combined effects of heavy metals on algae is available (Hollybaugh et al., 1980; Ahmed, 2003). The effect of combinations of different heavy metals should be studied in order to assess the impacts of heavy metals pollution on the primary producers of the food chains.

Results in the present study indicated that most of the combinations of the three heavy metals showed severe inhibition on algal growth. At the same time our results indicated that these heavy metals interact sometimes synergistically and other time antagonistically with each other on the inhibition of algal growth. Also, the data clearly documented concentration dependent toxic effects of the three heavy metals on growth, protein and chlorophyll contents of S. obliquus. The results are in agreement with the published data on algae by (Franklin $\boldsymbol{e t}$ al., 2002). They studied the individual and combined effects of copper, cadmium and zinc on the cell division rate of the tropical fresh water alga Chlorella sp., that significant interactions were observed for all metal combination. An equitoxic mixture of $\mathrm{Cu}+\mathrm{Cd}$ was synergistic to the growth of Chlorella sp., while combination of $\mathrm{Cu}+\mathrm{Zn}, \mathrm{Cd}+\mathrm{Zn}$ and $\mathrm{Cu}+\mathrm{Cd}+\mathrm{Zn}$ were antagonistic effect on the growth of Chlorella sp., which is in favor with our results. Pratima et al. (2001) found a degree of antagonism on the growth rate of the cyanobacterium 
Hapalosiphon stuhmanni and the photosynthetic green alga Scenedesmus quadricauda due to the combination of lead-nickel and cadmium-zinc. They explained the variations in antagonistic behavior to be due to the adsorption of one of the metal hindering the sorption of the other. Where the varied interactive behaviors were possibly because of either the formation of complexes with the algal exudes or the coagulation and co-precipitation of the metals with each other and their finding go parallel to our results.

The biotic effects of copper and zinc pollution are of particular interest because, although copper and zinc are essential trace element for both plants and animals. Where, copper it is strongly toxic at quite low concentrations. Although the toxicity of copper to different algal types varies greatly (Maloney and Palmer, 1956), the development of copper-tolerant strains has been reported for several algal species (Fitzgerald and Faust, 1963).

Silverberg et al. (1976) stated for the first time the copper tolerance mechanism in Scenedesmus sp. cells by incorporated into the nuclei. Furthermore, their study adds to the growing list of presently known metal pollutants capable of being sequestered in the form of intranuclear inclusions. Where, the formation of insoluble, intranuclear metal protein complexes is characteristic of some forms of heavy metal poisoning, particularly lead, bismuth and zinc, they have been reported in a variety of animal tissues and in moss leaf cells (Choie and Richter, 1972; Hsu et al., 1973; Skaar et al., 1973). Whereas, the origin of the protein in the inclusion bodies has been of great interest but has remained speculative (Goyer et al., 1970; Goyer and Rhyne, 1973).

It has been suggested by Moore and Goyer (1974) that the binding of such metals that occurs in the inclusion body serves as an adaptive or protective mechanism during transcellular transport. This mechanism has the effect of maintaining a relatively low cytoplasmic concentration of the metal and, therefore, reducing the toxic effects of metals on sensitive cellular functions. On the other hand, suggestions concerning the relative metabolic inertness of intracellular metal complexes receive some support in view of the finding that copper inclusions in the nucleus of B-4 cells are found at a concentration of copper lower than that which produces any signs of copper toxicity (Stokes $\boldsymbol{e t}$ al., 1973). The above interpretations may explain the presence of abundant dense bodies in the form of central dense-core complexes for S. obliquus experimented with in the present investigation.

\section{References}

Ahmed, E. A. (2003). Taxonomical and Physiological Studies on Some Algal Species, Isolated from Hyper -Saline Habitats and Its Role in Ameliorating Soil Characteristics Polluted With Heavy Metals. M.Sc. Thesis, Faculty of Science, Al-Azhar University (Girl Branch), Cairo, Egypt, 225pp. 
Allen, M. M., and Stanier, R. Y. (1968). Growth and division of some unicellular blue-green algae. J. Gen. Microbiol., 51:199-202.

Bariaud, A.; Bury, M. and Mestre, J. C. (1985). Mechanism of cadmium resistance in Euglena gracilis. Physiol. Plant, 63: 382-386.

Bourrelly, P (1968): Les algues d'eau douce 11 Les algues Jaunes et brunsn. Boubee and Cie, Paris, 438 pp.

Choie, D. D. and Richter, G. W. (1972). Lead poisoning: rapid formation of intranuclear inclusions. Science (Wash. D.C.), 177:1194 -1195.

Clark, R.B.; Frid, C. and Attril, M. (1997). Marine Pollution Clarendon Press. Oxford (Fourth edition). p 160.

Fitzgerald, G. P. and Faust, S. L. (1963). Factors affecting the algicidal and algistatic properties of copper. Appl. Micrabiol., 11:345-351.

Franklin, N.M.; Stauber, J.L.; Lim, R.P. and Petocz, P. (2002). Toxicity of metal mixtures to a tropical fresh water algae (Chlorella sp.): the effect of interactions between copper, cadmium, and zinc on metal cell binding and uptake. Environ. Toxicol Chem., 21: 2412-2422.

Goyer, R. A. and Rhyne, B. C. (1973). Pathological effect of lead. Int. Rev. Exp. Pathol., 12:1-77.

Goyer, R. A.; May, P.; Cates, M. M. and Krigman, M. R. (1970). Lead and protein content of isolated intranuclear inclusion bodies from kidneys of lead-poisoned rats. Lab. Invest., 22:245 251.

Guillard, R. R. L. (1995). Culture methods. In: Hallegraeff, G. M., Anderson, D. M., and Cembella, A. D., eds. Manualon Harmful Marine Microalgae. IOC Manuals and Guides No. 33. UNESCO, Paris, pp. 45-62

Hollybaugh, J. T.; Seibert, D. L. R. and Thomas W. H. (1980). A comparative of the acute toxicities of ten heavy metals to phytoplankton from Saanich Inlet. B. C. Canada. Estuarine Coastal. Mar. Sc., 10:93-105.

Hsu, F. S.; Krook, L.; Shively, J. N.; Duncan, J. R. and Pond, W. (1973). Lead inclusion bodies in osteoclasts. Science (Wash. D. C.), 181:447-448.

Hughes, E. O., Gorham, P. R., and Zehnder, A. (1958). Toxicity of a unialgal culture of Microcystis aeruginosa. Can. J. Microbiol., 4:225-36.

Jeffrey, S.W. and Humphrey, G. F. (1975). New Spectrophotometric equations for determining chlorophylls a, b, c1 and c2 in higher plants, algae, and natural phytoplankton. Biochem. Physiol. Pflanz., 167: 191-194.

Jegerschöld, C.; Arellano, J.B.; Schroder, W.P.; Van Kan, P.J.M.; Baron, M. and Styring, S. (1995). Copper (II) inhibition of electron transfer through photosystem 11 studied by EPR spectroscopy. Biochemistry, 34: 1274712754.

Kobbia, I. A; Dowidar, A. E.; Shabana, E. F., Al-Attar, S. A. (1993): Succession, Biomass levels of phytoplankton in the Nile water near the 
Starch and Glucose Factory at Giza, (Egypt). Egyptian Journal of Microbiology 28:131-143.

Krupa, Z.; Oquist, G. and Huner, N. (1993). The effects of cadmium on photosynthesis of Phaseolus Vulgaris - a fluorescence analysis. Physiologia Plantarum, 88:626-630.

Küpper, H.; Küpper, F. and Spiller, M. (1996). Environmental relevance of heavy metal - substituted chlorophyll using the example of water plants. J. of Exp. Botany, 47:259-266.

Lowry, O.H.; Resebrought, N.J.; Furr, A.L. and Randall, R.J. (1951): Protein measurement with folin phenol reagent. J. Biol. Chem., 193:265-275.

Magdaleno, A. Gomez, C.E.; Velez, C.G. Accorinti, J. (1997). Preliminary toxicity tests using the green alga, Ankistrodesmus falcatus. Environ. Toxicol. Water Qual., 12:11.

Mallick, N. and Rai, L. C. (1992). Metal induced inhibition of photosynthesis, photosynthetic electron transport chain and ATP content of Anabaena doliolum and Chlorella vulgaris interaction with exogenous ATP. Biomed. Environ. Sci., 5:241.

Maloney, T. E. and Palmer, C. M. (1956). Toxicity of 6 chemical compounds to 30 cultures of algae. Water Sewage Works, 103:509-513.

Moore, J. F. and Goyer, R. A. (1974). Lead induced inclusion bodies: composition and probable role in lead metabolism. Environ. Health Perspect., 7:121 127.

Olsson, R. W.; Abel, K. Sin, K. and Sin, K. G. (1979). Prokaryotic metallothionein: Preliminary characterization of a blue-green metal finding protein. Biochem. Biophy. Res. Common., 89:36-43.

Osman, M. E. H.; El-Naggar, A.H.; El-Sheekh, M. M. and El-Mazally, E.E. (2004). Differential effects of $\mathrm{Co}^{2+}$ and $\mathrm{Ni}^{2+}$ on protein metabolism in Scenedesmus obliquus and Nitzchia perminuta. Environ. Toxicol. Pharmacol., 16:169-178.

Padmini Sreenivasa Rao, P.; Sreenivasa Rao, P. and Karmarkar, S. M. (1986). Antibacterial substances from brown algae 1. Efficiency of solvents in the evaluation of antibacterial substances from Sargassum johnstonii Setchell et Gardner. Bot. Mar., 19:503-507.

Palade, G. E; Zagury, D; Uhr, J .W and Jamieson, J. D. (1952). Histoautoradiography study of immunoglobulin biosynthesis of mouse myeloma plasmacytes. Comptes Rendus Hebdomadaires des Séances de l'Académie des Sciences. Série D: Sciences naturelles, 268:1664-1667.

Pratima, M.; Angadi, S. B. and Mathad, R.D. (2001). Growth responses of Microalgae to multiple metal ion stress. Intern. J. of Ecol. \& Environ. Sci., 27:97-103. 
Rai, L. C.; Tyagi, B.; Rai, P. K. and Mallick, N. (1998). Interactive effect of UV-B and heavy metals $(\mathrm{Cu}$ and $\mathrm{Pb})$ on nitrogen and phosphorus metabolism of N2-fixing cyanobacterium Anabaena doliolum. Environ. Exp. Bot., 39:221.

Shaaban- Dessouki, S. A.; Deyab, M. A. and Mofeed, J. (2004): Phycological assessment of water quality of River Nile Delta- Egypt. Egyptian J. of Phycol., 5:18-34.

Silverberg, B. A.; Stokes, P. M. and Ferstenberg, L. B. (1976). Intranuclear complex in copper-tolerant green alga. J. cell Biol., 69:210-214.

Skaar, H.; Ophus, E. and GullvÄg, B. M. (1973). Lead accumulation within nuclei of moss leaf cells. Nature (Lond.), 241:215-216.

Stokes, P. M.; Hutchinson, T. C. and Krauter, K. (1973). Heavy metal tolerance in algae isolated from contaminated lakes near Sudbury, Ontario. Canad. J. Bot., 51:2155-2168.

Ting, Y.P.; Lawson, F. and Prince, I.G. (1991): Uptake of cadmium and zinc by the alga Chlorella vulgaris. II- Multi ion Situation. Biotechnol. Bioengineer., 37:445-455.

Toulibah, H. E. (1996): Ecological studies on the Nile River phytoplankton in relation to phsico-chemical characters at the area between Esna and Delta Barrage. Ph. D. Thesis, Fac. of Girls, Ain Shams Univ., Egypt, 203pp.

Umbriet, W.W.; Burris, R.H.; Stauffer, J.F.; Coheen, P.P.; Johsen, W.J.; lee Page G.A.; Patter, V.R. and Schneider, W.C. (1969): Manometric techniques, a manual describing methods applicable to the study of tissue metabolism. Burgess Publishing Co., USA, 239. 


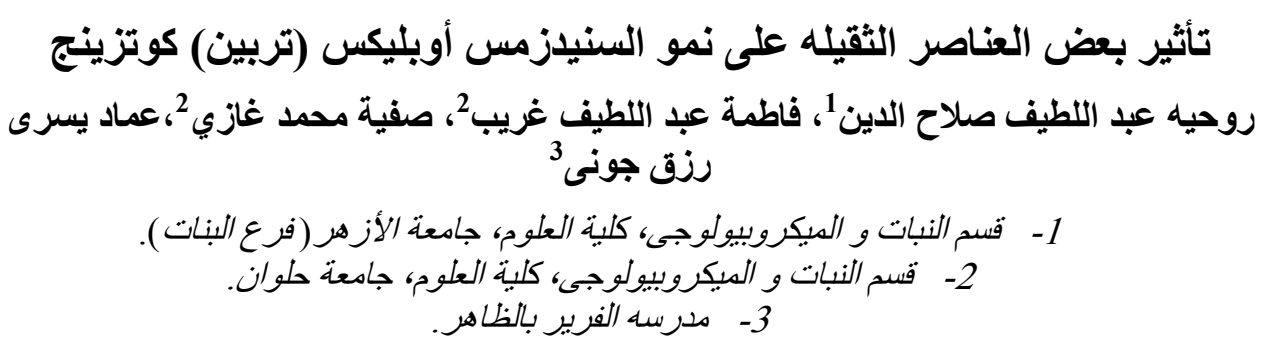

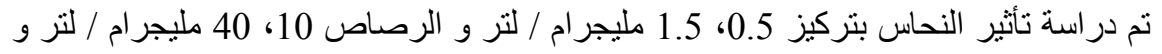

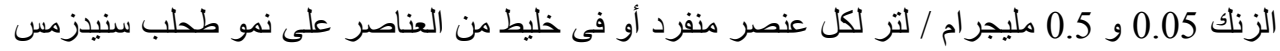

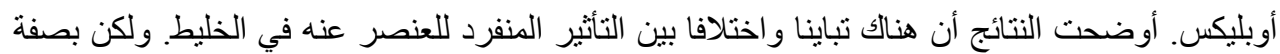

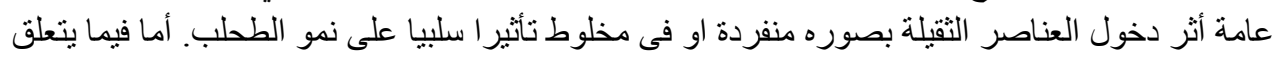

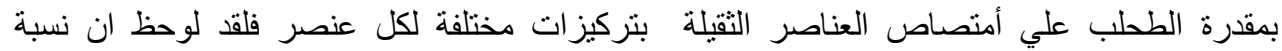

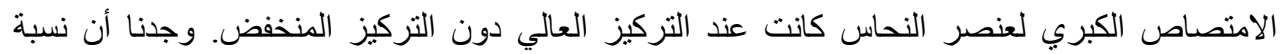

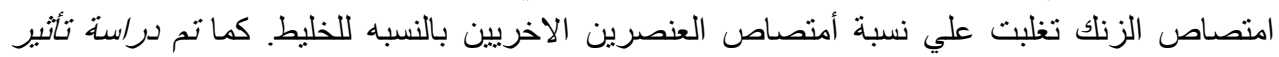

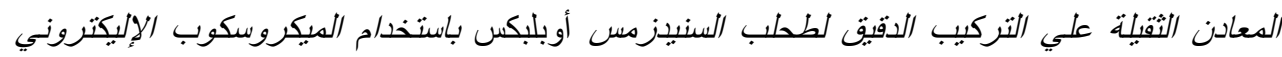

